Izabela Jankowska-Prochot (Warszawa)

\title{
Ewolucja instrumentów prawnych ochrony wiarygodności dokumentów w systemie common law na przykładzie Irlandii zależnej i niepodległej
}

\section{WPROWADZENIE}

Współczesny irlandzki system prawny tworzą orzeczenia precedensowe angielskich sądów sprzed 1922 roku, wynikająca ze staroceltyckiego prawa brehon tradycja historyczna oraz prawo stanowione w drodze legislacji, czyli postanowienia statutowe krajowego parlamentu (irl. Oireachtas) ${ }^{1}$.

W następstwie ekspansji angielskiej dokonanej w drugiej połowie XII wieku przez Henryka II Plantageneta, na Szmaragdowej Wyspie doszło do wielu istotnych zmian. Jedną z nich było wprowadzenie na podbitych ziemiach nowego porządku prawnego, który przez stulecia miał pierwszeństwo przed iryjskim reżimem prawnym. Normatywnych przykładów prymatu angielskiego common law można podać wiele, $\mathrm{z}$ uwagi jednak na zakreślone granice problematyki badawczej analizie poddano ustawodawstwo odnoszące się do kwestii podrabiania i przerabiania dokumentów.

Przedmiotem niniejszego artykułu są podstawowe zagadnienia związane z genezą, historycznym rozwojem oraz transferem rozwiązań prawnych dotyczących fałszerstwa materialnego dokumentów w irlandzkim ustawodawstwie karnym. Dopełnieniem tej analizy jest omówienie współczesnych znamion czynności

${ }^{1}$ Zob.: L. Ginel, The Brehon Laws: A Legal Handbook, Dublin 2010, s. 111-129 i 156-225; L. Campbell, S. Kilcommins, C. O'Sullivan, Criminal Law in Ireland. Cases and Commentary, Dublin 2010, s. 11-38. 
sprawczej, sankcji karnych oraz przesłanek ustawowych. O wyborze tematyki badawczej zadecydowały nie tylko osobiste zainteresowania autorki, ale również fakt, że zagadnienia te są w niewielkim stopniu przedmiotem refleksji naukowej, zarówno w literaturze polskiej, jak i światowej. Jest to pierwsze opracowanie poświęcone tej problematyce.

Realizacja tak postawionych celów implikowała dobór narzędzi metodologicznych w postaci interpretacji karnistycznej oraz metody historycznej. Pierwsza z nich pozwoliła na zbadanie języka prawnego oraz funkcji przepisów polegającej na jego związku z ,praktycznymi potrzebami społecznymi”’. Druga z kolei na zbadaniu historycznego rodowodu i porównaniu dogmatyki prawa w różnych okresach historycznych. Jej zastosowanie umożliwiło też zrozumienie specyfiki badanych instytucji prawnych oraz zbliżonej tożsamości anglosaskiej doktryny prawa karnego.

\subsection{REGULACJE PRAWNOKARNE DOTYCZACCE FAŁSZERSTWA MATERIALNEGO DOKUMENTÓW W IRLANDII ZALEŻNEJ}

Ustawodawstwo dotyczące fałszerstwa materialnego dokumentów wywodzi się z systemu prawnego starożytnego Rzymu. W edykcie pretorskim z 81 roku p.n.e autorstwa Lucjusza Korneliusza Sulli zatytułowanym Lex Cornelia testamentaria nummaria lub też Lex Cornelia de falsis znalazły się pierwsze regulacje dotyczące zabezpieczenia ogółu stosunków prawno-majątkowych po zmarłym. Na ich podstawie penalizowano fałszowanie zapisów testamentowych, pieczęci oraz matryc ${ }^{3}$. Ów akt prawny przewidywał też odpowiedzialność karną za pokrywanie kruszcem monet wykonanych z metali nieszlachetnych, używanie sfałszowanego testamentu, nałożenie pieczęci sfałszowanych na testament oryginalny czy też jego niszczenie ${ }^{4}$. W efekcie podejmowanych przez jurystów prac kodyfikacyjnych, zmieniającej się cesarskiej wykładni prawa oraz tła politycznego i historycznego tekst ten był wielokrotnie uzupełniany. Ostatecznie penalizacji poddano następujące zachowania: fałszowanie dokumentów o charakterze publicznym, składanie fałszywych zeznań, przekupywanie sędziów oraz podrabianie i przerabianie urzędowych jednostek miar i wag 5 .

${ }^{2}$ Cyt. za: R. Zawłocki, O metodzie interpretacji przepisów prawa karnego, „Ruch Prawniczy, Ekonomiczny i Socjologiczny" 2004, r. LXVI, z. 4, s. 82.

${ }^{3}$ Zob. też N. Kołoczka, Lucjusz Korneliusz Sulla [w:] Człowiek $w$ antycznym świecie, red. S. Sprawski, Kraków 2013, s. 233-262.

${ }^{4}$ Wspomina o tym K. Krężlewicz, Fatszowanie oznaczeń autorstwa w starożytnym Rzymie a ustawa 'Lex Cornelia dle falsis', „Zeszyty Prawnicze” 2014, nr 3(14), s. 152 i nn.

5 Zob. J.W.C. Turner, "Documents"in the Law of Forgery, 32 "Virginia Law Review" 1946, nr 32, 939, 941-943. 
Niebagatelne znaczenie dla kształtowania rzymskiego prawodawstwa w tym zakresie, a tym samym wpływ na kształt przyszłego prawa europejskiego miało zerwanie przez Juliusza Cezara z republikańskim zakazem umieszczania wizerunku osób żywych na monetach. Wprowadzenie do obiegu złotej monety Aureusa z wizerunkiem władcy na awersie i określonymi personifikacjami na rewersie, zrodziło prawną dopuszczalność wszczęcia postępowania karnego za manipulowanie obrazami i fałszowanie monet ${ }^{6}$. Okolicznością uzasadniającą bardziej surowe karanie sprawcy było uznanie tego przestępstwa za zdradę stanu, czyli czyn godzący w najistotniejsze interesy państwa. Tym samym we wczesnym prawie angielskim, a zarazem i irlandzkim przestępstwa fałszowania monet, pieczęci królewskiej oraz zdrady państwowej były ze sobą ściśle powiązane ${ }^{7}$.

Pierwszym aktem prawnym, w którym zdefiniowano zakres pojęciowy fałszerstwa, była uchwalona w 1562 r. ustawa zatytułowana przeciwko fatszerstwom dokumentów i treści (An act against forgeries of false deeds and writings) ${ }^{8}$. Pod jej rządami wyliczenie form zachowania się sprawcy miało charakter taksatywny, a do znamion określających czynność sprawczą zaliczono m.in.: podrabianie i przerabianie zbiorów praw wydawanych przez panującego, plomb oraz pieczęci, sądowych ksiąg latyfundiów, wierzytelności, zobowiązań rzeczowych i finansowych, pisemnych deklaracji o uiszczeniu lub zwolnieniu z długu, powództw, wyroków itp. Szczegółowo wyliczono też konsekwencje, które mogły być skutkiem „małej, łagodnej i lekkiej kary”, wymierzanej dotychczas za ten typ

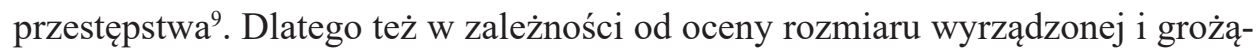
cej szkody oraz stopnia godności sprawcy i ofiary wśród dopuszczalnych sankcji przewidziano te o charakterze fizycznym i odwetowym. Do kategorii pierwszej zaliczano: zakucie w dyby, chłostę pod pręgierzem oraz wszelkie kary mutylacyjne $^{10}$. Do drugiej zaś przepadek mienia na rzecz władcy oraz zadośćuczynienie w postaci podwojonego zwrotu kosztów i szkód na rzecz poszkodowanego. Obok kar ściśle określonych ustawodawca dopuszczał także możliwość stosowania nieokreślonych, o których arbitralnie decydował monarcha. Należała do nich m.in.

${ }^{6}$ Zob. P. Freeman, Julius Cesar, New York - London - Toronto - Sydney 2009, s. 172 i nn.

7 Zob. szerzej: The Law Reform Commission. An Coimisiǔn Um Athchǒiriǔ An Dli (LRC 43 1992). Report on the law relating to Dishonesty. Chapter 6. Forgery, counterfeiting and related matters, s. $70 \mathrm{i} \mathrm{nn.}$

${ }^{8}$ Zob. 5. Elizabeth c. 14 [w:] W.D. Evans, A. Hammond, T.C. Granger, A Collection of Statutes Connected with the General Administration of the Law, t. 6, London 1836, s. 95.

${ }^{9}$ Ibidem, s. 97.

${ }^{10}$ Do najpopularniejszych kar okaleczających zaliczano obcinanie uszu czy rozcinanie nozdrzy, przypiekanie gorącym żelazem „by ślady pozostały trwałą pamiątką po popełnionej zbrodni”. Cyt. za: 28 Elizabeth c 3 [w:] D. Evans, A. Hammond, T.C. Granger, A Collection of Statutes..., s. 259. Wspomina o tym także F. Stephen, A History of the Criminal Law of England, London 2009, s. $177 \mathrm{i} \mathrm{nn.}$ 
kara dożywotniego pozbawienia wolności ${ }^{11}$. Ustawa statuowała też typ uprzywilejowany fałszerstwa w przypadku, gdy sfałszowany dokument dotyczył majątku ruchomego, służebności gruntowej, zwolnienia z długu czy też innych osobistych zobowiązań ${ }^{12}$. W późniejszym okresie, w związku z dążeniem do zapewnienia kontynuacji tradycji rodowej oraz z uwagi na wysoki stopień społecznej szkodliwości fałszowania testamentów, przestępstwo to uznano za ścigane z urzędu, z oskarżenia prywatnego.

Definicja fałszerstwa tym razem ograniczona do „nielegalnego naśladownictwa każdego przedmiotu, urzędowo stwierdzającego istotną kwestię o charakterze publicznym, uregulowaną w rejestrze parafialnym, innym dokumencie prawnym lub testamencie" znalazła się w ustawie z $1733 \mathrm{r}^{13}$. Warto przy tym podkreślić, że z punktu widzenia teoretyków prawa karnego oraz stanowiska judykatury ze szczególnym uwzględnieniem koncepcji wykładniczych przyjmowanych przez Sąd Koronny (ang. Crown Court) podrabianie czy też przerabianie dokumentów o niższej randze nie było uznawane za fałszerstwo ${ }^{14}$. Poza rangą dokumentu brano także pod uwagę zachowanie sprawcy. Ustawodawca uznał bowiem, że do wypełnienia znamion tego występku nie jest wystarczające samo złożenie nieprawdziwego dokumentu, ale także celowe działanie mające na celu wprowadzenia w błąd innej osoby czy osób. Wolę tę oceniano oczywiście poprzez weryfikację zewnętrznych zachowań sprawcy.

W kolejnych latach wzrastająca świadomość prawna społeczeństwa spowodowała, że rozproszone dotychczas przepisy regulujące problematykę fałszowania monet $\mathrm{i}$ dokumentów zostały skonsolidowane $\mathrm{w}$ jednym akcie prawnym ${ }^{15}$. Pierwszym z nich była ustawa z 1830 r., w której znacznie złagodzono sankcję za fałszerstwo dokumentów ${ }^{16}$. Normatywnym wyrazem tego faktu stały się głębokie przeobrażenia obowiązującego $\mathrm{w}$ tamtym okresie systemu prawnego i wykorzy-

115 Elizabeth c. $14 \ldots$, s. 95.

12 Karą grożącą za tego typu przewinienia było obcięcie wyłącznie jednego z uszu i pozbawienie wolności do jednego roku. Ibidem, s. 96.

${ }_{13}$ Zob. Forgery Act 1733 (7. Geo II c. 22) [w:] D. Evans, A. Hammond, T.C. Granger, A Collection of Statutes..., s. 102. Zob. też D.J. Cox, Crime in England 1688-1815, London 2014, s. 158; W. Hawkins, A Treatise of Pleas of the Crown, London 1824, s. 263.

${ }_{14}$ Zob. The Law Reform Commission...s. 70.

15 Analiza wyroków składów orzekających Sądu Izby Gwiaździstej dowodzi, że przyczyn tego legislacyjnego rozproszenia należy upatrywać w fakcie, że czynność sprawcza ujmowana jako „fałszowanie dokumentów" popełniana była stosunkowo rzadko. Znacznie powszechniejszym występkiem było fałszowanie monet i pieczęci państwowych. Niezależnie od powyższego nowa podstawa legislacyjna uchyliła obowiązujące uprzednio i rozproszone w wielu aktach prawnych regulacje dotyczące zdrady państwowej i fałszowania monet. Wspomina o tym: J.F. Stephen, A History of the Criminal Law...s. 177 i nn.

${ }^{16}$ Zob. The Forgery Act, 1830 (11 Geo 4 \& 1 Will 4 c 66) [w:] J. Stephen, New Commentaries on the Law of England, London 2003, s. 180. 
stanie klauzul derogacyjnych (ang. - repealing clause), do znacznego skrócenia listy czynów zagrożonych dotychczas egzekucją ${ }^{17}$.

Kolejnym aktem prawnym była ustawa z $1861 \mathrm{r}$. zwana także Aktem konsolidacyjnym (ang. The Consolidation Act) ${ }^{18}$. Zgodnie z brzmieniem jego przepisów przestępstwa dotychczas uznawane za zdradę stanu, jak fałszowanie Wielkiej czy też Tajnej Pieczęci Królewskiej oraz podrabianie podpisu monarchy zostały uznane za występki przeciwko wiarygodności dokumentów i nie były już karane pozbawieniem sprawcy życia ${ }^{19}$. Najsurowszą karą przewidywaną w ustawie było skazanie na przymusowe roboty.

Akt ten składał się z 43 sekcji, z czego w 25 z nich w sposób niezwykle precyzyjny i drobiazgowy definiowano różnego rodzaju przestępstwa ${ }^{20}$. Odnosiły się one nie tylko do bicia monet czy destabilizowania brytyjskiego systemu monetarnego, ale także podejmowania jakichkolwiek przygotowań zmierzających do popełnienia przestępstwa. Ustawodawca kryminalizował więc podrabianie złotych, srebrnych czy metalowych monet, rozjaśnianie metalu służącego do wytopu tych ostatnich czy bezprawne posiadanie opiłków żelaza. Karalne było także sprzedawanie monet poniżej ich wartości rynkowej, samodzielne lub oparte na współpracy wprowadzanie sfałszowanych dokumentów do obiegu. Dużo miejsca poświęcono też podrabianiu, przerabianiu i używaniu jako autentycznych dokumentów skarbowych, papierów wartościowych, skryptów dłużnych, przekazów pieniężnych czy zleceń maklerskich ${ }^{21}$. Do znamion fałszerstwa materialnego zaliczono również posiadanie oraz sprzedaż matryc lub papieru z napisem „Bank of England”, „Bank of Ireland”22. Ustawa określała także odpowiedzialność karną za fałszowanie rejestrów gruntów, zobowiązań do stawiennictwa na rozprawie, pi-

17 Śmiercią karano wówczas jedynie za fałszowanie najważniejszych pieczęci państwowych. Wyłączono zaś możliwość stosowania tej kary za podrabianie i przerabianie rachunków skarbu państwa oraz innych publicznych papierów wartościowych, banknotów, testamentów, weksli, warrantów i innego rodzaju bonów subskrypcyjnych, zleceń na wypłatę pieniędzy etc. Ibidem.

18 The Forgery Act 1861 (24 \& 25 Vict c 98) [w:] Ch.S. Greaves, The Criminal Law Consolidation and Amendment Act of the $24 \& 25$ Vict; with Notes and Observations 1862, London 2015, s. $144 \mathrm{i} \mathrm{nn.}$

19 Zob. szerzej: 24 i 25 Vic. C. 90 [w:] Ch.S. Greaves, The Criminal Law Consolidation and Amendment Act of the 24 \&25 Vict: with Notes and Observations 1862, London 2015, s. $144 \mathrm{i} \mathrm{nn.}$

${ }^{20}$ Owa precyzja oraz uznanie, że fałszerstwo dokumentów to przestępstwo godzące w pewność obrotu prawnego czy ekonomicznego, nie zaś zdrada stanu, pozwoliło nie tylko na uniknięcie technicznych i aksjologicznych luk w prawie, ale także zróżnicowanie dolegliwości karnej dla sprawców przestępstw. Do czasu obowiązywania tego aktu prawnego kara grożąca zabójstwo monarchy, podrobienie ręcznego podpisu, odcisku jego sygnetu czy Tajnej Pieczęci była taka sama. Ibidem.

${ }^{21}$ Zob. szerzej: Section 8-13 oraz 32, ibidem.

${ }^{22} \mathrm{O}$ najistotniejszych postanowieniach ustawowych wspomina także P.R. Glazebrook, Blackstone's Statutes on Criminal Law 2015-2016, Oxford 2016, s. 4 i 36-37. 
semnych oświadczeń woli złożonych pod przysięgą, wyroków oraz postanowień irlandzkich oraz angielskich sądów polubownych i ziemskich ${ }^{23}$.

Za kwalifikowany typ przestępstwa uznano fałszowanie sądowej księgi latyfundiów, zwanej także sądową księgą wiejską, w której rejestrowano przebieg i skutki czynności prawnych toczących się przed ławniczym sądem wiejskim²4 Do tej samej kategorii zaliczono złożenie przez osobę nieuprawnioną i w imieniu kogoś innego podpisu na wypłacie kaucji zabezpieczającej wierzytelność, sfałszowanie zeznań oskarżonego oraz przejęcie nieruchomości na podstawie podrobionych lub przerobionych aktów notarialnych. Co ciekawe, trzy przestępstwa przeciwko wiarygodności dokumentów uregulowane kolejno w sekcjach 34, 36 i 37, dotyczące fałszowania rejestrów urodzeń, aktów małżeństwa i zgonu oraz przybieranie cudzej tożsamości obowiązują w brytyjskim i irlandzkim prawie karnym do dnia dzisiejszego ${ }^{25}$. Nowelizacja ustawy w 1870 r. rozszerzyła zakres indywidualny przedmiotu ochrony o interesy niemajątkowe innej osoby ${ }^{26}$.

Ostatni akt prawny rangi ustawowej dotyczący fałszerstw materialnych dokumentów, opracowany przez brytyjski parlament, lecz obowiązujący także w Irlandii, powstał w $1913 \mathrm{roku}^{27}$. I tak w $\S 1$ wspomnianej regulacji zawarto syntetyczną definicję fałszerstwa, zgodnie z którą pod pojęciem tym rozumiano „złożenie jako autentycznego nieprawdziwego dokumentu lub posłużenie się sfałszowaną pieczęcią czy też matrycą w celu wprowadzenia w błąd innej osoby"28. Istota tego czynu karalnego sprowadzała się więc do łącznego spełnienia dwóch przesłanek: użycia nieautentycznego dokumentu lub pieczęci oraz podjęcia zabiegów mających na celu zrodzenia w świadomości pokrzywdzonego błędnego obrazu rzeczywistości. Poza zakresem penalizacji z art. 1 ww. ustawy pozostawała zatem sytuacja, w której sprawca zrobił co prawda użytek z nieprawdziwego dokumentu, jednak bez zamiaru wprowadzenia innej osoby w błąd.

${ }^{23}$ Warto w tym miejscu podkreślić, że te ostatnie, określane mianem Landed Estetes Court funkcjonowały niemal wyłącznie w Irlandii i zostały powołane w celu zorganizowania sprzedaży lub wynajmu wyludnionych po klęsce Wielkiego Głodu domów i gospodarstw rolnych. Zob. R.Ch. Macnevin, The Practice of the Landed Estates Court in Ireland from the Institution to the Conclusion of the Proceedings, Third Edition, Dublin 1859, passim.

${ }^{24}$ Zob. szerzej: Section 30 The Consolidation Act..., op.cit.

${ }^{25}$ Zob. 24 (j) Section 4 Forgery [w:] Criminal Justice (Theft and Offences), Act, 2001 oraz 5 (i) Section 5 Offences Relating to Money Orders, Share Certificates, Passports, etc. [w:] Forgery and Counterfeiting Act 1981, http://www.irishstatutebook.ie/eli/2001/act/50/enacted/en/html; http://www.legislation.gov.uk/ukpga/1981/45/section/5 [dostęp: 01.04.2017].

${ }^{26}$ Powyższy akt prawny został uchylony w 1893 r. Zob. szerzej: The Forgery Act, 187057 \& 58 Vic C 56 [w:] Halsbury's Status of England, 2nd Edition, s. 850 oraz Statut Law Revision Act, 1893, http://www.irishstatutebook.ie/eli/1893/act/14/section/1/enacted/en/html, [dostęp: 01.04.2017].

${ }^{27}$ Zob. szerzej; C.S. Kenny, J.W.C. Turner, Outlines of Criminal Law, Cambridge 2013, s. 368 i nn.

${ }^{28}$ Cyt. za: Section 1 (1) Forgery Act, 1913,http://www.legislation.gov.uk/ukpga/1913/27/section/1/enacted [dostęp:01.04.2017]. 
Ustawodawca zamieścił także w art. 2 definicję legalną sfałszowanego dokumentu. Stosownie do jego treści miał nim być dokument, którego całość lub jakakolwiek część została wystawiona przez osobę, czy też w imieniu osoby, która nie wyraziła na to zgody albo nie posiadała uprawnień do jego wystawienia; został sporządzony w niedozwolonym czasie lub miejscu, bądź też którego znaczące fragmenty lub numer zostały zmienione.

W szczególności zaś dokument uznawany był za fałszywy, gdy:

a) dokonano w nim jakichkolwiek zmian przy użyciu środków mechanicznych, w formie dodania lub usunięcia poprawek, retuszów, wstawek lub uzupełnień,

b) jego część lub całość została sporządzona w imieniu osoby fikcyjnej lub zmarkej,

c) został sporządzony przez lub w imieniu istniejącej osoby, organu władzy lub podmiotu prawnego w intencji wprowadzenia w błąd osoby trzeciej,

d) został sporządzony przez osobę prawdziwą lub fikcyjną, inną jednak niż ta która byłą uprawniona do jego wystawienia ${ }^{29}$.

Co ciekawe i znamienne, pomimo szczegółowej definicji fałszerstwa i sfałszowanego dokumentu ustawodawca expressis verbis nie sprecyzował, jakie znaczenie pragnie nadać dokumentowi jako takiemu. Przyczyn tego stanu należy upatrywać w fakcie, że w odniesieniu do tego zagadnienia występowały bardzo odmienne podejścia doktrynalne ${ }^{30}$. Na ogół jednak przeważał pogląd, że było nim

${ }^{29}$ Zob. art. 2, ibidem.

${ }^{30}$ Debata na temat zakresu treściowego terminu rozpoczęła się z inicjatywy sędziów brytyjskiego sądu odwoławczego w sprawach karnych (ang. Court for Crown Cases Reserved) jeszcze w latach 70. XVIII w. W orzecznictwie pojawiło się wówczas zapatrywanie, że malarz, który podpisał swe dzieło nazwiskiem innego artysty, nie tyle dopuścił się fałszerstwa, co oszustwa. Jako wyraz poglądu sformułowanego przez londyński Sąd Apelacyjny w tym wyroku należy przytoczyć opinię sędziego Sir Alexandra Cockburn'a, zdaniem którego „czynność sprawcza fałszerstwa musi dotyczyć dokumentu lub tekstu pisanego”. Jeśli zaś owa sygnatura była jedynym pisemnym a zarazem identyfikacyjnym znakiem na obrazie, to brak jest podstaw do uznania go za fałszerstwo. Podobną argumentację zastosował sędzia Charles Edward Pollock w sprawie rzekomego podrobienia przez producenta proszku do pieczenia opakowań, w których sprzedawał ten produkt. Zdaniem przewodniczącego skopiowanie wzoru torebek trudno uznać za fałszerstwo, bo są one jedynie obwolutą, nie zaś dokumentem czy instrumentem prawnym. Przekonanie to adekwatnie ilustruje także inny fragment wypowiedzi arbitra: „(...) uznanie takiego czynu za fałszerstwo pozwalałoby w przyszłości twierdzić, że jeżeli jeden kupiec owija sprzedawane przez siebie towary w brązowy papier, a drugi zacząłby czynić tak samo, to i jego można by oskarżyć o fałszowanie brązowego papieru". Z takim stanowiskiem korelowała także opinia sędziego Georgea Bramwella, który zwrócił uwagę na wyraźną różnicę między opakowaniami. Otóż w wersji „oryginalnej” znajdowało się krótkie ostrzeżenie o możliwych dolegliwościach żołądkowych w przypadku przedawkowania produktu. Brak analogicznej adnotacji na drugim opakowaniu sprawiał, że w opinii sędziego „był on tak samo prawdziwy, jak oryginalny, tyle że wadliwy”. Przytoczono za: The Law Reform Commission...s. 74 i nn. 
opatrzone własnoręcznym podpisem lub odciskiem stempla pisemne oświadczenie woli, które chroniło określone dobro lub też pozwalało na zapisanie informacji, ewidencji czy obietnic mających znaczenie prawne ${ }^{31}$.

W dalszej części ustawy uregulowane zostały najpoważniejsze przestępstwa przeciwko wiarygodności dokumentów, zagrożone karą ciężkich robót, w wymiarze nieprzekraczającym 14 lat, o ile sprawca popełnił je z zamiarem oszustwa (ang. deceive) lub sprzeniewierzenia (ang. defraud) ${ }^{32}$. Do czynów tych, poza fałszowaniem królewskich pieczęci, sygnetów i podpisów, należało także podrabianie lub przerabianie aktów prawa cywilnego i ksiąg metrykalnych, w tym świadectw urodzenia, metryk chrztu, ślubu, śmierci czy kremacji. Do tej samej kategorii zaliczono także fałszowanie kopii oraz uwierzytelnionych odpisów ww. dokumentów, zaświadczeń upoważniających do pobierania rent rządowych oraz dokumentów wystawionych przez lub pod nadzorem Komisarza Urzędu Skarbowego (ang. Commissioners of Inland Revenue) lub Komisarza Urzędu Ceł i Akcyzy (ang. Commissioners of Customs and Excise).

Zagrożone siedmioletnią karą ciężkich, przymusowych robót było popełnione w zamiarze oszustwa lub defraudacji przestępstwo fałszowania dokumentów oraz ich urzędowo poświadczonych kopii takich jak: księgi buchalteryjne, certyfikaty, zaprzysiężone zeznania oraz zaświadczenia wydane przez sędziego pokoju, urzędnika stanu cywilnego oraz lekarza psychiatrę w sprawie choroby umysłowej pacjen$\mathrm{ta}^{33}$. Do odrębnej kategorii funkcjonariuszy publicznych wystawiających dokumenty podlegające szczególnej ochronie prawnej należeli też rzeczoznawcy budowlani, urzędnicy sądowi, zatrudnieni w organach ścigania oraz sędziowie sądów postępowania pisemnego (ang. Court of Record) ${ }^{34}$. Łagodniejszą dolegliwość karną, bo nie przekraczająca dwóch lat pozbawienia wolności lub ciężkich robót, przewidziano dla sprawców fałszerstw dokumentów innych niż wymienione powyżej.

Obowiązująca kodyfikacja karna z 1913 r. zapewniała bardziej surowy reżim ochrony prawnokarnej przed fałszowaniem pieczęci i matryc. Do najbardziej

${ }^{31}$ Ibidem, s. 76.

32 Różnicę między dwoma terminami przystępnie wyjaśnił sędzia John Buckley w obiter dictum z 1903 roku (In re London and Globe Finance Corporation, [1903] 1 Ch 728, at 732-733).. Wyjaśnia on w nim, że pod pojęciem deceive należy rozumieć czynność sprawczą polegającą na świadomym wprowadzeniu w błąd innej osoby. Natomiast defraud polega na podstępnym doprowadzeniu innej osoby do niekorzystnego rozporządzania majątkiem osobistym lub cudzym. Innymi słowy celem oszustwa jest zmiana stanu umysłu pokrzywdzonego, sprzeniewierzenia zaś wymuszenia przy pomocy podstępu określonego działania. Ibidem.

${ }_{33}$ Zob. szerzej: Section 8. Forgery [w:] Commissioners for Oaths Act, 1889, dostepny w internecie: http://www.legislation.gov.uk/ukpga/Vict/52-53/10/section/8 [dostęp: 02.04.2017].

${ }^{34}$ Więcej na temat specyfiki funkcjonowania sądów postępowania pisemnego i wpływu na stanowione precedensy zob. J. Jaślan, H. Jaślan, Słownik terminologii prawniczej i ekonomicznej angielsko-polski, Warszawa 1991, s. 174. 
strzeżonych, których fałszerstwo było zagrożone sankcją dożywotniego pozbawienia wolności lub przymusowych robót, należały m.in.: Wielka Pieczęć Wielkiej Brytanii, królewskie faksymile, sygnet Lorda Strażnika Tajnej Pieczęci oraz Wielka oraz Tajna Pieczęć Irlandii ${ }^{35}$. Wśród pozostałych ustawodawca wymienił też należące m.in. do: Państwowych Archiwów Notarialnych, sądów postępowania pisemnego oraz Generalnego Rejestratora Aktów Prawa Cywilnego. Do bytu karalnego zagrożonego karą czternastu lub siedmiu lat katorgi zaliczano także podrabianie innych niż ww. pieczęcie.

Ustawodawca penalizował też posługiwanie się sfałszowanymi dokumentami, pieczęciami lub matrycami oraz przewidywał taką samą odpowiedzialność karną jak za ich podrobienie czy przerobienie. Znamię czasownikowe „posługuje się" oznaczało w tym wypadku używanie, ogłaszanie, pozywanie, wystawianie na sprzedaż ect.

Analizowana ustawa zakresem swojej kryminalizacji obejmowała także żądanie wydania mienia na podstawie sfałszowanych dokumentów (jak m.in. testament, kodycyl, papiery dłużne); posiadanie bez wymaganego pozwolenia nieautentycznych dokumentów, pieczęci, matryc narzędzi, znaczników do frankowania złota, srebra i metalu; sreber stołowych i innych kosztowności oraz metali nieszlachetnych; jakikolwiek pieczęci wymienianych w ustawie o opłacie skarbowej z 1891 roku lub też należących do Komisarza Urzędu Skarbowego lub Komisarza Urzędu $\operatorname{Cet}^{36}$.

Konstrukcja tej czynności sprawczej stanowiła również podstawę do sankcjonowania zachowań na przedpolu naruszenia rodzajowego przedmiotu ochrony, czyli odpowiadających przygotowaniu do fałszerstwa. Należało do nich np.: wytwarzanie czy też posiadanie papieru lub narzędzi służących do wytwarzania m.in. weksli skarbowych, deklaracji podatkowych czy fałszowania innych dokumentów; kupowanie lub posiadanie określonych formularzy i blankietów przed ich ostemplowaniem lub oficjalna emisją. Za winną była też uznawana każda osoba, która świadomie i umyślnie pomagała, doradzała, przyczyniała się, czerpała korzyści lub zlecała dokonanie fałszerstwa.

Intencją legislatora było pozostawienie szerokiego zakresu uznania sędziowskiego. Stąd też na mocy sekcji 12 niniejszej ustawy, przewodniczący składu orzekającego,po uwzględnieniu stopnia winy i społecznej szkodliwości czynu mógł zamienić karę ciężkich robót na karę pozbawienia wolności z wykonywaniem lub niewykonywaniem ciężkich robót, w okresie nieprzekraczającym dwóch

${ }^{35}$ Zob. też An Act for the Union of Great Britain and Ireland, 2nd July 1800 Chapter 67 (39 and 40 Geo 3).

${ }_{36}$ Zob. Stamp Duties Management Act, 1891, http://www.legislation.gov.uk/ukpga/Vict/5455/38/contents [dostęp: 02.04.2017]. 
lat. Możliwe było także orzeczenie innej kary, o ile była zgodna z obowiązującym prawem. W przypadku najpoważniejszych fałszerstw zagrożonych katorgą lub pozbawieniem wolności sąd mógł również zażądać od sprawcy wpłacenia kaucji pieniężnej zawierającej lub niezawierającej poręczenia od gwaranta. Z powodu nieznalezienia poręczycieli oskarżony nie mógł być jednak pozbawiony wolności w okresie dłuższym niż jeden rok.

\subsection{REGULACJE PRAWNE W IRLANDII NIEPODLEGŁEJ}

Separatyzm historyczno-polityczny, który doprowadził do podpisania w 1922 r. Traktatu angielsko-irlandzkiego i powstania Wolnego Państwa Irlandzkiego, składającego się z 26 południowych hrabstw, nie oznaczał jednak pełnego zerwania więzi prawnych z Imperium Brytyjskim. W dalszym ciągu trwała konwergencja brytyjskiej kultury legislacyjnej oraz obowiązywały uprzednio uchwalone prawo statutowe.

Zmiany nastąiły dopiero w 2001 roku, kiedy to uchwalona została ustawa Wymiar sprawiedliwości (Przestępstwa nadużyć finansowanych i kradzieży) z 2001 roku (ang. Criminal Justice - Theft and Fraud Offences Act, 2001) ${ }^{37}$. W rozdziale czwartym przywołanego unormowania prawodawca zamieścił przepisy regulujące przestępstwo fałszerstwa materialnego dokumentów. Jego konstytutywnymi cechami, poza definicjami legalnymi fałszerstwa, szkody wyrządzonej przestępstwem oraz podżegania do dokonania czynu zabronionego, są także regulacje dotyczące używania, kopiowania oraz wykorzystywania kopii podrobionych lub przerobionych dokumentów. Penalizacji poddano także sprawowanie nadzoru i kontroli nad ich wytwarzaniem.

W obowiązującym stanie prawnym definicja dokumentu została określona w rozdziale 24 cytowanej ustawy, zatytułowanym „objaśnianie wyrażeń ustawowych". Zgodnie z tym przepisem do kategorii tej zaliczonych zostało osiem grup przedmiotów. Pierwszą z nich stanowią dokumenty binarne, zapisane na wszelkich możliwych informatycznych nośnikach danych ${ }^{38}$. Drugą potwierdzające bezgotówkowe transfery pieniędzy. Należą do nich m.in.: przekazy pieniężne, pocztowe i bankowe, akredytywy, listy przewozowe, czeki, euroczeki, inkaso, inkaso samochodowe oraz wszelkie elektroniczne instrumenty płatnicze. Trzecia wyróżniona kategoria obejmuje wybrane akcydensy manipulacyjne, takie jak etykiety opłaty skarbowej wykorzystywane do regulowania należności za usługi przez instytucje publiczne, jak urząd pocztowy (irl. An Post) czy urząd skarbowy

${ }^{37} \mathrm{http}: / / w w w . i r i s h s t a t u t e b o o k . i e / e l i / 2001 /$ act/50/enacted/en/html [dostęp: 02.04.2017].

${ }^{38}$ Do owych nośników ustawodawca irlandzki zalicza „dysk, taśmę, ścieżkę dźwiękową lub inne narzędzia mechaniczne czy elektroniczne”. Zob. art. 24 a Criminal Justice ..., op.cit. 
(irl. Ioncam Intire) oraz znaczki pocztowe w formie matrycy lub samoprzylepnej. Do kategorii tych ustawodawca zalicza też licencje i pozwolenia wydane przez urząd skarbowy. Odrębny rodzaj stanowią certyfikaty inwestycyjne, zbywalne prawa majątkowe, akcje i obligacje oraz inne papiery wartościowe, wyemitowane na podstawie przepisów prawa irlandzkiego lub wspólnotowego. Zakres przedmiotowy dokumentów obejmuje również wydawane przez kierownika stanu cywilnego (irl. Tard-Chláraitheoir) wpisy o urodzeniu, małżeństwie i zgonie a także dokonaniu przysposobienia. Dwie osobne kategorie stanowią dokumenty uprawniające do korzystania $\mathrm{z}$ administracyjnych, społecznych i technicznych usług publicznych oraz dokumenty podróży.

Stosownie do treści art. 30. (1) za dokument nieautentyczny uznaje się taki, w którym poświadczony został nieprawdziwy stan rzeczy i który w celu użycia go jako oryginalnego:

a) nie został sporządzony w przepisanej prawem formie i przez powołane do tego osoby czy też organy władzy publicznej,

b) został sporządzony w przepisanej prawem formie, jednak przez nieuprawniony do tego organ,

c) został sporządzony przy niezachowaniu określonych prawem terminów,

d) został sporządzony w czasie, gdy organ nie posiadał uprawnień do jego wystawiania,

e) został przerobiony w jakimkolwiek zakresie przez osobę lub organ, który nie był uprawniony do przeprowadzania tych zmian

f) został przerobiony w następstwie nieprawidłowości zachodzących w psychice wystawcy, definiowanych jako taki czas, okoliczności i warunki zewnętrzne, które wymuszają określone zachowanie,

g) został wykonany lub przerobiony przez osobę lub organ w rzeczywistości nieistniejący.

Zachowanie wyczerpuje zatem w pełni dyspozycję art. 31. (1), o ile sprawca działał w celu osiągnięcia korzyści osobistej lub majątkowej, a sporządzony przez niego dokument zawiera nieprawdziwe dane. Istota tego czynu karalnego sprowadza się zatem do:

- spreparowania nieprawdziwego dokumentu,

- działania z nastawieniem na określony cel, w postaci wprowadzenia w błąd lub wyzyskania błędu innej osoby,

- przedłożenie sfałszowanego dokumentu i doprowadzenie do niekorzystnego rozporządzenia mieniem przez inną osobę.

Współcześnie do bytu karalnego zalicza się także używanie sfałszowanego dokumentu. Niezbędnym do przypisania tej osobie sprawstwa konieczne jest jednak wykazanie, że miała ona świadomość, że przedkłada dokument zawierający nieprawdziwe dane i czyni to w celu wyrządzenia realnej szkody innej osobie. 
Istota winy polega też na przekonaniu poszkodowanego co do autentyczności dokumentu i rozporządzenia majątkiem w sposób niekorzystny z punktu widzenia interesów własnych lub innej osoby pokrzywdzonej.

Czyn zabroniony zostaje dokonany, gdy sprawca

- posługuje się sfałszowanym dokumentem,

- wie lub wierzy, że dokument, którym się posługuje jest nieautentyczny,

- dąży do wprowadzenia w błąd lub wyzyskanie błędu innej osoby,

- doprowadza do niekorzystnego rozporządzenia mieniem przez inna osobę.

Zbędna jest przy tym kumulatywna kwalifikacja prawna przestępstwa w postaci sfałszowania i posługiwania się sfałszowanym dokumentem. Oznacza to, że znamiona tego czynu zabronionego może zrealizować zarówno osoba, która sama podrobiła lub przerobiła dokument, jak i ta, która ,jedynie” się nim posłużyła.

$\mathrm{Z}$ uwagi na fakt, że w irlandzkich regulacjach prawnych brak definicji normatywnej terminu „użycia” należy przyjąć, że chodzi o zaakceptowanie definicji językowej zgodnie z którą oznacza on „posługiwanie się czymś” lub „użytkowanie czegoś" ${ }^{39}$. Nieodzowną przesłanką takiego przekonania będzie zatem uznanie, że jakiekolwiek formy świadomego wykorzystania sfałszowanego dokumentu są wystarczające do wypełnienia znamion strony przedmiotowej występku. W analogiczny sposób trzeba również zinterpretować pojęcia „wie lub wierzy”. Dzięki wykorzystaniu semantycznej dyrektywy interpretacyjnej pojęcie pierwsze należy tłumaczyć, jako „posiadanie określonej wiedzy” oraz „zdawanie sobie z czegoś sprawy” drugie zaś jako „przyjmowanie czegoś za prawdę” Istotny jest przy tym fakt, że sprawca wypełnia ustawowe znamiona przestępstwa sankcjonowanego przepisem art. 26. (1) także wtedy, gdy dokument jest autentyczny, on jednak trwa w mylnym przekonaniu, iż został sfałszowany i nie podejmuje żadnych działań by wyprowadzić z błędu innej osoby lub osób.

Kolejny typ fałszerstwa polega na kopiowaniu sfałszowanego dokumentu. Przy realizacji tego inkryminowanego zdarzenia niezbędne jest łączne spełnienie czterech warunków. Są nimi:

- sporządzenie kopii,

- wiedza lub wiara sprawcy, że dokument oryginalny jest falsyfikatem,

- zamiar zrodzenia w świadomości pokrzywdzonego zafałszowanego obrazu rzeczywistości,

- powstanie realnej szkody w mieniu pokrzywdzonego. Szkoda w tym wypadku rozumiana jest jako przejściowa lub nieodwracalna utrata składników majątkowych, możliwości zarobkowania lub otrzymywania innych gratyfikacji finansowych niż uposażenie ${ }^{40}$.

\footnotetext{
${ }^{39}$ A Plain English Guide to Legal Terms, Dublin 2003.

${ }^{40}$ Definicja szkody przytoczona za: art. 31. (1.) Criminal Justice..., op.cit.
} 
Do omawianego katalogu przestępstw przeciwko wiarygodności dokumentów należy również posługiwanie się kopią sfałszowanego dokumentu. Przesłanki tego czynu zabronionego, poza wprowadzeniem w błąd innej osoby, względnie wyzyskanie jej błędu co do autentyczności dokumentu, doprowadzenia jej w ten sposób do niekorzystnego rozporząazenia mieniem własnym lub powierzonym, obejmuje także celowe wykorzystanie nielegalnego duplikatu oraz zamiar kierunkowy.

Czyn zabroniony zostaje dokonany także w sytuacji sprawowania nadzoru lub kontroli nad dystrybucją sfałszowanych dokumentów lub ich kopii, lub dysponowania wiedzą na temat przygotowania, usiłowania lub dokonania czynu zabronionego określonego w rozdziale czwartym cytowanej ustawy. By czyn wypełniał jednak dyspozycje wzmiankowanych przepisów, konieczne jest zarazem świadome skorzystanie lub doprowadzenie pokrzywdzonego do błędnego przekonania o realiach, w jakich się znajduje, i wyrządzenie mu szkody. Sprawcą tego przestępstwa może być też osoba dokonująca nieuprawnionych zmian w dokumencie autentycznym lub sprawująca nadzór nad dokumentami, co do których ma pewność lub ugruntowane przekonanie, że są fałszywe. By postawić sprawcy zarzut zachowania niezgodnego z normą prawną, konieczne jest jednak udowodnienie, że elementy przedmiotowe fałszu materialnego były mu znane i że pragnąc otrzymać nienależną mu korzyść majątkową wprowadził w błąd inną osobę. Ostatni rodzaj normatywnej charakterystyki zachowania sprawcy statuuje dwa typy czynu zabronionego: sporządzenie fałszywych dokumentów oraz czynienie przygotowań do ich sporządzenia, polegających na posiadaniu maszyn, pieczątek, znaczków lub innych materiałów oraz ich przysposabianiu do potrzeb planowanego deliktu. W obu zachodzi także prawna jedność przestępstwa, gdyż i jeden, i drugi stanowią realizację tego samego zamiaru przestępczego. Jest nim wprowadzanie w błąd innej osoby, wyzyskanie jej błędu czy też niezdolności do właściwego pojmowania realizowanego działania w celu osiągnięcia korzyści majątkowej.

\section{PODSUMOWANIE}

Zręby instytucji prawnych, które znamy obecnie, a których celem jest sprawność funkcjonowania i bezpieczeństwo obrotu prawnego, a także indywidualne interesy uczestników tego obrotu powstawały już w starożytnym Rzymie. Początkowo obejmowały one regulacje dotyczące tworzenia falsyfikatów testamentów, pieczęci oraz matryc, z czasem zaś fałszowania dokumentów o charakterze publicznym, urzędowych jednostek miar i wag a także złotych i srebrnych monet. Sukcesorem rzymskiej kultury prawnej była natomiast zdecydowana większość krajów europejskich. 
W procesie kształtowania się prawa irlandzkiego dotyczącego fałszerstwa materialnego dokumentów niezwykle istotną rolę odegrał rozwój ustawodawstwa angielskiego. Pierwsze regulacje prawne w tym obszarze pojawiły się już w 1562 r. w ustawie przeciwko fałszerstwom dokumentów i treści (An Act against Forgeries of False Deeds and Writings), W niej też dokonano wyliczenia czynów zabronionych, tradycyjnie określanych mianem przestępstw przeciwko wiarygodności dokumentów, oraz kar mutylacyjnych grożących za ich popelnienie. Później, w związku z wejściem w życie ustawy z 1733 r. zatytułowanej Fałszerstwo (The Forgery Act 1733), opracowano definicję legalną tego czynu przestępczego. Regulacje nie miały jednak jednolitego charakteru normatywnego, a wysokość kary była uzależniona po pierwsze od rangi dokumentu, po drugie od statusu prawnego i społecznego oskarżonego, po trzecie od pozycji majątkowej i stanowej pokrzywdzonego.

Reformy z lat 30. XVIII w. były kontynuowane także latach w 30. XIX w. $\mathrm{W}$ ich wyniku unormowania legislacyjne dotyczące szeroko rozumianych fałszerstw zostały skonsolidowane w jednym akcie prawnym (The Forgery Act, 1830). Następnie nie tylko znacznie złagodzono sankcje za fałszerstwo dokumentów, ale i uproszczono oraz unowocześniono procedury sądowe.

Kolejnej zmiany dokonano w 1861 roku. Nowa podstawa legislacyjna znosiła zarówno dotychczasową kwalifikację czynu jako przestępstwa zdrady państwowej, jak i karę śmierci za fałszowanie dokumentów. Od tej pory najwyższym wymiarem kary miały być roboty przymusowe.

W 1913 roku brytyjski parlament wydał ostatni już akt rangi ustawowej dotyczący fałszerstwa dokumentów i obowiązujący także na terytorium Irlandii. Po 1922 roku, mimo nieustannych przeobrażeń mentalnych, kulturowych, a przede wszystkim politycznych, związanych z odzyskaniem przez kraj niepodległości, nie doszło jednak do rozłamu prawnego i sądowniczego na Szmaragdowej Wyspie. Bezpośrednią przyczyną harmonizacji i podobieństwa merytorycznego norm prawnych obowiązujących w obu państwach była wymuszona okolicznościami wspólnota doświadczeń i częściowo wspólnota językowa ${ }^{41}$. Warto podkreślić, że obecnie obowiązująca ustawa karna, uchwalona wyłącznie przez irlandzki Oireachtas, powstała dopiero w $2001 \mathrm{r}$. i w porównaniu z uregulowaniami obowiązującymi poprzednio w węższym stopniu reguluje problematykę fałszerstwa materialnego dokumentów. Przejawem tego faktu jest, że przepisy te zostały umieszczone w jednym rozdziale ustawy o wymiarze sprawiedliwości i przestępstwach nad-

${ }^{41} \mathrm{~W}$ efekcie wielowiekowych prób wynarodowiania Irlandczyków w początkach XX wieku w języku gaelickim biegle posługiwało się mniej niż 30\% obywateli tego kraju. Zob. szerzej: A. Doyle, A History of the Irish Language, Oxford 2015, s. 161 i nn. 
użyć finansowych i kradzieży (ang. Criminal Justice 〈Theft and Fraud Offences〉 Act, 2001) zatytułowanym Fałszerstwo (ang. Forgery).

Warto wspomnieć, że dostrzegalne jest znaczne podobieństwo miedzy treścią przepisów rozdziału pierwszego aktualnie obowiązującej brytyjskiej ustawy O fałszowaniu i podrabianiu (ang. Forgery and Counterfeiting Act) z 1981 r. oraz rozdziału czwartego irlandzkiej ustawy Wymiar sprawiedliwości (Przestępstwa nadużyć finansowych i kradzieży) (ang. Criminal Justice «Theft and Fraud Offences> Act 2001). Analogie widać w definicji legalnej dokumentu, która w obu wypadkach ogranicza się do wymienionych taksatywnie przedmiotów. Katalog wymieniony w ustawie irlandzkiej jest szerszy niż brytyjski. Identyczne jest natomiast karnoprawne brzmienie definicji sfałszowanego dokumentu oraz określeń identyfikujących podmiot fałszerstwa. Tak samo zostały również sformułowane wszystkie wyszczególnione typy czynu zabronionego. W obu ustawach obejmują one: sporządzanie nieprawdziwych dokumentów, ich kopiowanie, używanie, używanie ich kopii oraz sprawowanie nadzoru i kontroli nad wytwarzaniem fałszywych dokumentów lub przygotowania do popełnienia przestępstwa

\author{
EVOLUTION OF LEGAL INSTRUMENTS USED TO PROTECT \\ THE CREDIBILITY OF DOCUMENTS IN THE COMMON LAW SYSTEM ON \\ THE EXAMPLE OF IRELAND UNDER FOREIGN RULE \\ AND OF INDEPENDENT IRELAND
}

\begin{abstract}
The aim of the analysis presented in the following article is to delineate the historical outline and the evolution of the criminal law regulations in the area of forgery of documents in Ireland under foreign rule and in independent Ireland. Special emphasis is placed on the implementation of English and later British legal solutions in Ireland as well as on their substantive similarities. A significant part of the deliberations is also devoted to modern regulations in the aforementioned area. Special attention is paid to the culpability (sometimes called the subjective element of a crime or Mens rea in Latin) and conduct (sometimes called the objective element of a crime or Actus reus in Latin) side of crime. Another discussed element is the punishment one is subjected to for committing the said offense. The study of the present issues is based on both the statutory interpretation of the previous and current regulations as well as on the doctrine and judicature. The assumed objectives and research problems as well as the used methodology have a direct correlation to the structure of the article. The paper consists of an introduction, chapters devoted to the formation of the previously mentioned legal regulations in Ireland under foreign rule and in independent Ireland as well as conclusions.
\end{abstract}




\section{ÉVOLUTION DES INSTRUMENTS JURIDIQUES VISANT À PROTÉGER LA CRÉDIBILITÉ DES DOCUMENTS DANS LE SYSTÈME COMMON LAW SUR L'EXEMPLE DE L'IRLANDE DÉPENDANTE ET INDÉPENDANTE}

\section{Résumé}

L'article vise à donner un aperçu historique de la réglementation pénale et son évolution dans le domaine de la falsification matérielle des documents en Irlande dépendante et indépendante. Un accent particulier a été mis sur l'implantation des solutions juridiques anglaises et ensuite britanniques et leur similitude substantielle. Une partie considérable de nos considérations est également consacrée à la réglementation en vigueur à cet égard, en tenant compte du sujet et de l'objet de l'infraction et la peine pour l'avoir commise.

L'étude de ces questions est basée aussi sur l'interprétation des textes légaux préexistants et les règlements actuels que sur les opinions doctrinales et judiciaires. Les objectifs adoptés et les problèmes de recherche ainsi que la méthodologie utilisée ont eu un impact direct sur la structure de l'article. Il se compose de l'introduction, des chapitres consacrés à l'élaboration des règlements juridiques mentionnées en Irlande dépendante et indépendante et de la conclusion. 